\section{Kort og konsist om klinisk suicidologi}

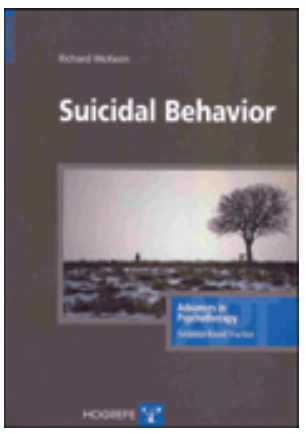

\section{Richard McKeon \\ Suicidal behavior}

104 s, tab, ill. Cambridge, MA: Hogrefe Publishing, 2009. Pris USD 30 ISBN 978-0-88937-327-3

Er det mulig å gi en god og praktisk nyttig, oppdatert oversikt over klinisk suicidologi på knappe 90 sider? Svaret er ja. Denne boken, skrevet av den amerikanske psykologen Richard McKeon, er en systematisk og logisk oppbygd fremstilling av fagfeltet, der lite eller intet er overflødig stoff. Forfatteren er en av dem som har stått sentralt i utviklingen av den amerikanske føderale strategien for selvmordsforebygging, men han har også mangeårig erfaring som kliniker og leder innenfor helsevesenet.

Det er tydelig at det er klinikeren som taler i Suicidal behavior, som ikke desto mindre er godt underbygd med referanser til sentral forskningslitteratur. Det er fire kapitler og tallrike nummererte avsnitt. Først diskuterer forfatteren grundig definisjonsmessige problemer knyttet til suicidal og selvskadende atferd og peker på de mange fallgruvene som upresis begrepsbruk kan skape på dette kliniske feltet. Dernest tar han for seg alle de sentrale oppgavene klinikere må ivareta i møte med suicidale pasienter - vurdering og dokumentasjon av selvmordsrisiko, kriseintervensjon, planlegging av behandling og plan for pasientsikkerhet. Han presenterer ulike psykoterapeutiske teknikker rettet mot de forskjellige psykologiske og atferdsmessige aspektene ved suicidalitet og drøfter hvordan behandlingen bør legges opp i tidlige og senere faser. Her er det mange gullkorn å hente for interesserte lesere.

Forfatteren er svært opptatt av å styrke kontinuiteten i pasientbehandlingen, noe som er særlig viktig når vi vet at selvmordsrisikoen ofte ikke går over så fort og ikke sjelden er forhøyet $\mathrm{i}$ lang tid etter at den verste krisen er over. McKeon argumenterer også sterkt for at man bør konsentrere seg om suicidaliteten i pasientkontakten og behandlingen så lenge den er til stede. Mange klinikere kan ha en tendens til å unnlate å fokusere så direkte på suicidalitet. Det kan ha flere årsaker, bl.a. antakelsen om at når man behandler den underliggende psykiske lidelsen, vil selvmordsrisikoen avta. Men det er lite bevis for en slik slutning. Siden suicidale pasienter ofte er blitt systematisk utelukket fra kliniske effektstudier av legemidler og psykoterapi, er deres effekt på suicidal atferd ofte ukjent. Suicidaliteten bør derfor behandles direkte.

Slike klare anbefalinger er det mange av her, og de blir ofte presentert i tekstbokser, kalt «clinical pearls». Uten å strekke kunnskapsgrunnlaget for langt evner forfatteren å gi klare retningslinjer for praksis, noe leserne utvilsomt vil finne nyttig. Praktisk nyttig er det også at de viktigste poengene i hvert avsnitt står med fet skrift i margen, at det er mange korte, kliniske vignetter samt to lengre kasuspresentasjoner og at det finnes et appendiks med tilleggsressurser. Språklig er stilen lettlest og ledig. Og omfanget er meget overkommelig. Jeg anbefaler den herved varmt for alle som arbeider med suicidale pasienter.

\section{Lars Mehlum}

Nasjonalt senter for selvmordsforskning og -forebygging Institutt for klinisk medisin Universitetet i Oslo

\section{Sterk beretning om en familietragedie}

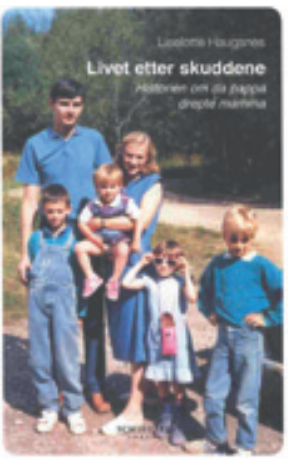

Liselotte Haugsnes

Historien om da pappa drepte mamma. $239 \mathrm{~s}$. Oslo: Schibsted Forlag, 2010. Pris NOK 339

ISBN 978-82-516-3556-1

Denne boken er ført i pennen av Liselotte Haugsnes, et av de fire barna til Johan Bjerkvik, ansett kommunelege og familiefar i Våler, Hedmark. Bjerkvik var en av de mange helsearbeiderne som ga alt for pasientene, men som ikke klarte å sette grenser og ta vare på sitt eget liv. Et økende indre stress og periodiske depresjoner førte til bruk, og etter hvert misbruk, av vanedannende medikamenter. Det akselererende misbruket kunne etter hvert ikke skjules. Først mistet han legelisensen og så sitt eget ekteskap, før han tok livet av sin fraseparerte ektefelle Maria og deretter seg selv dagen etter hennes 50 -årsdag.

Beretningen kan grovt deles i to. I den første delen får vi innblikk i forfatterens oppvekst $i$ en ressurssterk familie med engasjerte foreldre, frem til de fatale skuddene falt 2. februar 2004. Deretter følger vi forfatteren og hennes søsken i deres forsøk på å reorientere seg og bygge opp livet på nytt. Noen undertemaer vokser frem i fortellingen. Ett grunntema er fallet til en mann alle respekterte og beundret og den rollen rusmidler spilte i fallet, et annet hvor bredt og dypt en dramatisk hendelse som drap i familien rammer. Johan Bjerkviks skudd rammet ikke bare hans fraseparerte ektefelle og ham selv eller bare deres barn - et helt lokalsamfunn blir som lammet etter en slik hendelse. Et dramatisk og uventet dobbeltdrap avslører hvor skjør vår sosiale orden er og hvordan tilliten som eksisterer mellom mennesker kan bli rystet i sine grunnvoller når dem vi stoler på svikter eller viser et annet ansikt.

Forlagsredaktøren har gjort en god jobb. Der mange av de pasient- og pårørendeberetningene jeg har lest, er preget av at de er ført i pennen av mennesker som ikke har skrevet før, er forfatterens manglende litterære bakgrunn snudd til en styrke i Liselotte Haugsnes' beretning. Språket er enkelt og direkte og gir et rytmisk driv til en ærlig og naken fortellerstil. Vi kommer tett på forfatteren, faren og de andre hovedpersonene, uten at det oppleves som for privat eller utleverende. Refleksjonene rundt hendelsesforløpet og årsakene til Johan Bjerkviks dramatiske valg er enkle og konkrete. Spørsmålene dirrer i luften etter lesingen og etterlater undring heller enn svar.

Liselotte Haugsnes har uttalt at hennes hovedbudskap er: Bry dere! Dette budskapet har hun fătt igjennom. Boken munner ut i et ja til livet. Det går an å kjempe seg gjennom slag og traumer, men beretningen viser hvor avgjørende andres støtte og nærvær kan være og hvor små marginer som skiller en vellykket helbredelsesprosess fra et fatalt fall som rammer alvorlig og bredt. Dette er en beretning som vil berøre mange lesere, som stoff til refleksjon og påminnelse om hvor skjørt livet er.

\section{Audun Myskja}

Senter for livshjelp

Ski 